\title{
Customer-oriented Sales Management Mode - Study of Marketized Operation based on Provincial Broadcast Groups
}

\author{
Ruoqian Yang \\ Department of Economic Management, Xinyang Normal University Huarui College, \\ Xinyang, 464000, China
}

\begin{abstract}
Broadcast network, telecommunications network and Internet underpin the development of the information industry. The integration of them three is an inevitable trend of the modern IT industry. In this context, provincial broadcast groups are confronted with unprecedented challenges and opportunities, among which customers are a key element. This paper explores the customer-oriented sales management mode based on the marketized operation of provincial broadcast groups with Henan CATV Group as the illustrative case.
\end{abstract}

Keywords: Sales Management, Customer-oriented, Broadcast Groups.

\section{Introduction}

In the market background which gives prominence to the "User First" notion, only by focusing on customers can the development be possible, and only through building a customer-oriented sales management mode can the development of provincial broadcast groups be facilitated[1-3].

Henan CATV Group is a network multiservice operator concentrating on the transmission of cable TV signal. It is the main body for the implementation of cable TV network integration and overall conversion of digital in Henan Province, which is ascertained by Henan Provincial Party Committee and Henan government, making itself a key supporting cultural group in Henan Province. The network of Henan CATV Group covers 18 municipalities under the provincial authorities and 108 counties (cities). Currently the provincial trunk network is $4000 \mathrm{~km}$, the trunk from municipalities to countries 6500 $\mathrm{km}$ and the inter-city trunk between municipalities 20000 $\mathrm{km}$. The network features high capacity, quality and safety, taking the lead in China. Henan CATV Group headquarters lies in Zhengzhou and offers services to 3800 thousand cable subscribers in municipalities[4-5].

Since 2005 the company has been integrating network and accelerating the pace of cable network integration, working hard to promote the integration of broadcast network, telecommunications network and Internet. Later on, it started integrating the province's network by means of capital operation, introduction of the strategic partner CITIC Group, fund-raising and fund purchasing.

\section{Advantages and Disadvantages of Henan CATV Group in Marketing}

\subsection{Advantages}

Henan CATV Group (Henan Cable) forges its advantageous brand through years' operation. As an important means of Party and government publicity, it has built a harmonious relationship with local governments and media, plus the fact that it features a wide range of coverage with a large number of 3800 thousand cable subscribers. Going through reforms, it also grows very fast and now steadily forms a marketing innovative atmosphere within the group. Many of its marketing talents are well-educated with high artistic attainment and mature marketing knowledge. Besides, Henan Cable has amassed much practical experience so far. With special emphasis on staff training, Henan Cable endeavors to enhance the comprehensive abilities of staff by various kinds of training schemes given that the current market has placed relatively high requirements on staff[6-7].

\subsection{Disadvantages}

Although Henan Cable has gone marketized and accomplished the integration of the whole network, there is still much to be desired in its internal staff's creativity and market awareness due to the long-term impact of state planned economy. With the market development, marketing concepts change every day, but there are not many, especially among the frontline mangers, adept at new marketing concepts in Henan Cable even though there are many more proficient in market operation. Furthermore, Henan Cable's immature marketing management as well as lack of a set of effective marketing operational mechanism and standardized marketing process poses some impediments for the overall interest of the company. In the wake of market and social development, marketing concepts evolve too. 


\section{Construction of Customer-oriented Sales Management Mode}

\subsection{Customer-oriented Marketing}

The customer-oriented notion is an important theory in marketing. Thus, constructing a customer-oriented marketing system becomes a must in marketing activities. The construction demands the achievement of the following aspects:

1. Long-term Partnership with Customers

Traditional marketing channels are absolute trading means, every one of which is an independent business entity going in its own way for benefit maximization. In the modern society with ever-changing conditions, the sales intermediate channels' quality varies greatly, thus companies must select a well-reputed customer and take advantages of the customer's complete sales network and good credit to set up a long-term partnership with him. Only in this way can companies discover marketing changes in time, seize the opportunity to draw up marketing strategies and remain invincible. Customers also need to build a long-term stable relationship with companies. Therefore, there comes the relational marketing channel which aligns manufacturing units with channel members for systematic benefit maximization. Its worthiness lies in the cooperativity of strategic process, two-way attribute of information communication, and mutual benefit of marketing activities. Companies' longterm partnership with customers should be illuminated in the factors as follows:

(1) Companies should give prominence to the principle of serving customers wholeheartedly and transfer the channel center from distributors to customers. Companies must establish a customer-oriented operating guideline and take customer satisfaction as the main objective and serving customers wholeheartedly as the principle when formulating channel strategies and conducting channel management so as to transfer the channel center from distributors to customers. Customer satisfaction is a key factor in determining customer loyalty. As long as customers are loyal, companies' sales activities can possibly be successful.

(2) Companies should keep their channel strategies in line with customer objectives. So, it is inevitable for every company to reassess their existing channels. The biggest obstacle in the reassessment lies in the conflict between the existing customer management pattern and management strategies. Therefore, the necessary doing is to start from scratch, that is, to get rid of the present channel arrangement and to find an optimal way to open up the market from the behind. After nailing down the target customer groups, companies should consider how to gain access to them. In this case, channel strategies must be in line with the overall strategies of companies, cater to necessary efficiency requirements (reasonable return rate) and maintain long-term flexibility.

(3) Companies and customers should take the advantage of the company capacity of one another to achieve the amplification of their own. Since the training of company capacity is a long-term manpower-, resourceand money-sapping process, along with the unpredictability of company capacity, the training can be very difficult. Companies' building a sound relationship with customers helps win more competitive edges while the mutual sharing of company capacity will help increase the returns of companies.

(4) Companies should adopt new marketing tools and treat all customers equally. For instance, they must not categorize customers by regions, treating customers from remote areas and from cities differently. The different departments in Henan Cable should also enjoy the same treatment. Whether it is for technology, customer service or marketing, all staff members should be given equality.

\subsection{Customer-oriented Marketing Planning}

Companies have shifted their customer management concentration from assistant sales to assistant operation. Assistant sales means that companies send out some staff members to various places and get them involved in the local sales activities. Assistant operation means that companies assist customers in formulating overall marketing plans, training marketing professionals, aiding and guiding the implementation of marketing plans, and offer intellectual support to customers. Companies' customer management has turned a new leaf, from the microscopic concentration on the present to the macroscopic concentration on the future prospect through helping customers formulate management terms, comb through the downstream sales channels, and enhancing customers' managerial capacity of downstream sales channel management and control. This practice can be illuminated in the factors as follows:

1. From result-centric to process-centric; the key of channel management lies in the enhancement of process management upon channels and members. Process management covers the whole process of channel management which implies various links between operators, customers and consumers. Channel process management indicates the operation and track of channels while the objective of process management upon channel members is to ensure the orderliness and efficient running of channels.

2. Building of professional channels and network development team. Most sales teams from most companies have sales awareness only instead of channel or network awareness. They are good at selling goods but not at building sales channels or network. Without a professional development team, a tailor-made sales channel or network can in no way be possible. Companies should help customers build up the sales team, comb the 
sales network, and work hard on the training of sales staff by imbuing them with the modern and classic marketing concepts and knowledge.

\subsection{Building of Two-way Information Communication with Customers}

Sociology deems relationships the organic channel between information and emotional communication. A good relationship brings a free-flowing channel while a bad one causes channel blockade and an interrupted one poses channel jam. Since communication is two-way, it can start from companies or channel members. Extensive information communication and information sharing can win companies support and collaboration. In the original customer management system, information flows from the manufacturers to customers in the stream of product sales in terms of product specification, category, price, sales status, etc. During this process, information flow shows a strong unidirectional trend along with little amount, asymmetry and negative interaction between senders and receivers. Some companies may probe into the conditions of consumers and sales channels through the initiative in market survey and information gathering, but they tend to neglect the channel policies and promotional details that customers can readily offer. In this case, the information messaging and feedback via sales channels is not fully used, thus impacting the timeliness, accuracy and roundedness of information. Companies must form a mature system of information gathering, feedback, collation and processing so as to provide references for the management's decision-making and business departments' formulating marketing strategies. Information gathering comes first whose key lies in accumulation and sharing of customer resources. Second, not all the information is useful, thus screening and refining it becomes a must to form valuable customer and market knowledge. Third, before building two-way information communication, companies and customers should learn the information needs and market changes of one another so as to ensure smooth communication. The practice of companies' not using modern information technology to set up a mature information system with customers can be a nightmare. Only by building a twoway information management system between companies and customers can the role of information be called into play in marketing and competition. Besides, companies are in the face of the ever-changing customer management mode. During the process of customer management, appraisals of customers' distribution channel mode and organizations, assessments of customers' compliance rate, credit status, sales capacity, cooperative attitude, business efficiency are both necessary.

Customer services are a key part directly relative to whether the customer group of Henan Cable grows or not. So employing customer-oriented marketing theory to read customer services and make improvement is necessary.
Customer services facilitate the building of two-way information communication with customers. Henan Cable's original customer services used to be monotonous, e.g. communication only existed when customers contacted the customer service center of their own accord while the customer service center seldom tried to gather customers' information. Consequently, companies were confronted with passivity in all their work, which attested to a matter of conception. Companies must form an operational system for information gathering, feedback, collation and processing, place emphasis on customer services by learning about customers' problems spontaneously instead of waiting for customers who are already in trouble. Taking initiative provides references for the management's decision-making and business departments' formulating marketing strategies, and moreover, does good to the relationship with customers.

\subsection{Customer-oriented Marketing Management Measures}

There is a fact that demands attention: a lot of companies take "customer-oriented" as their solo objective but fail to achieve it. Such a situation must be avoided. An important measure to solve this problem is to combine the pursuit of "customer-oriented" with other objectives. If the management of a company wants to realize the "customer-oriented" objective but the staff of middle and lower-level can only satisfy customers in line with an old management mode, then staff's practice deviates from the management's strategy and line of thought. Thus, it is necessary to construct the "customeroriented" corporate culture and integrate it with other objectives.

Companies must attach importance to customers' information during the sales process. Accurate customer information matters very much to companies but the attainment of timely, accurate and comprehensive information must be on the basis of effective customer relationship management method support. First, as information technology is booming, it has become a musthave element in marketing and for customer relationship management. In this regard, the Internet offers a wider space for companies, with which companies can enhance their sales effectiveness, expand sales coverage, develop sales extended channels, obtain larger market share than their rivals and thus gain better return. In practice, it is noteworthy that when there are new channels to be develop and old ones to be maintained, companies need to think over how to coordinate the two in the same region. Second, "team sales" is another important rule in customer relationship management. With the rapid development of economic globalization and information technology in the $21^{\text {st }}$ century, the opening of new markets, the unprecedented change in sales behavior, the high-speed information transmission and the large amount of information have changed the pattern of the competition between companies as well as the mode of 
sales work. Thus, a well-trained sales team has become the criterion for a company's adaptability to this new requirement. A sales team must be armed with proficient marketing skills, collaboration ability and adeptness at building customer relationship. Moreover, the information and knowledge of an individual needs to be shared within the team, which facilitates the internal communication, mutual learning, developing the strong points and avoiding the weak ones, and common progress, and gives prominence to the team performance. Third, companies should immerse their sales staff in one common notion the "customer-oriented" objective by implementing customer relationship management. The notion enlightens the sales staff as to the fact that everyone is part of the team, and it is not one, but the whole team, in the face of customers. Everyone should work closely with one another in handling customer relationship. And only through the sharing of information and resources can the overall interests be maximized, thus every individual can gain benefit from it. Therefore, companies should streamline staff members by imbuing them with a "master" awareness in the internal training and educate them to abide by the principle of "customer-oriented, customer-centric".

Companies should construct their teams in light of the "customer-oriented" objective. Without the backup of a team, the objective can be impossible. Such things as enhancement of customer satisfaction, procedure cycle reduction, quick response, cost cut, creative new product and services development must be done in the meantime. To fulfill this, a team is required. In a team, the personnel can play a part for the "customer-oriented" purpose. So, relevant training must be done so that every staff member knows how to combine his own work with the objective.

\section{Two Noteworthy Issues in Implementing Customer-oriented Sales Management Mode}

i . Advancement of internal mechanism construction; due to the information asymmetry caused by the market economy features and low quality in most business agents, there are few agents who can really grasp customers' needs. In most cases, agents cannot manage customers effectively for limitations of their own abilities or the absence of support from companies. Instead, sometimes they are controlled by customers. In other words, agents can only support sales rather than manage customers. Although some companies in China have realized the importance of customer management, but none of them bestow the rights of reward and punishment on business agents owing to the immature mechanism of companies or semi-skilled managers. The cause lies in the mutual distrust between both, which forms the main reason in ineffective customer management. Thus companies should strengthen their internal mechanism management to give business agents enough trust, in response to the old saying "hire the man you trust and trust the man you hire". With system support, agents can make good use of the rights of reward and punishment - awarding customers by means of "granting more line of credit, offering more promotional support and staff support, applying special awards from the company", and punishing customers by "reducing line of credit, repealing staff support, confiscating guarantee money, cancelling year-end bonus, reducing promotional support". Customer management is art that demands sales capacity and quality in business agents and the rights of reward and punishment as well as trust bestowed by companies. In the meantime, companies must make a self-examination to enhance their management level so as to run the internal mechanism efficiently. Only by combining the two aspects above together can companies or business agents control customers to achieve sales quotas and fulfill benefit maximization.

ii . Overall grasp and planning of three procedures: (1) to fully understand customers' needs for product or service and consider customer information and materials as the strategic resources of companies. Since companies' customer numbers are directly relative to the economic benefit of them, customer satisfaction determines the survival of companies. (2) To analyze customer needs in a conscientious way, especially personalized needs. Companies should pointedly improve the quality of their products or services to meet customers' expectation and needs so as to achieve a "win-win" situation. (3) Companies should make a change to their sales and marketing pattern and set up the one-to-one marketing model. By establishing effective marketing and sales strategies to build up better customer relationship, companies can fulfill the sustainable increase of benefit, promote the transformation of internal mechanism, and finally accomplish the "customer-oriented" operational mode. On the whole, customer relationship management is a new management mechanism in improving the relationship between companies and customers. It covers a wide range of customer-related areas including marketing, sales management and customer services. Customer relationship management gives prominence to the role of customers, revealing the "customer-directed" operational concept in modern companies. China's companies need to learn more about existing and potential customers if they try to implement customer relationship management and employ the most updated technologes to judge rivals' behavior more precisely and promptly. In particular, the internal management mechanism must be adaptable to the complex changes of the market. Only in this way can companies gain higher economic benefit, customer satisfaction to meet the increasingly fierce competition in the international and domestic market. 


\section{Conclusion}

In this paper, we conduct research on customeroriented sales management mode based on the study of marketized operation based on provincial broadcast groups. Broadcast network, telecommunications network and Internet underpin the development of the information industry. With system support, agents can make good use of the rights of reward and punishment - awarding customers by means of "granting more line of credit, offering more promotional support and staff support, applying special awards from the company", and punishing customers by "reducing line of credit, repealing staff support, confiscating guarantee money, cancelling year-end bonus, reducing promotional support". Customer management is art that demands sales capacity and quality in business agents and the rights of reward and punishment as well as trust bestowed by companies. In the recent future, we will optimize the current model to achieve the better performance.

\section{.References}

[1] Bian Fangjun, Marketing Planning, Guangdong Economic Publishing House: Guangzhou, pp.40-45,
2005.

[2] Luo Ziming, Consumer Psychology, Tsinghua University Press: Beijing, pp.72-76, 2004.

[3] Yao Junfeng, On Customer Relationship Management - Building "Customer-oriented" Operational Mode, Jing Ji Shi, (07), pp. 240-241, 2010.

[4] Wang, C. Y. , Service quality, perceived value, corporate image and customer loyalty in the context of varying levels of switching costs, Psychology and Marketing, 27(3), pp. 252-262, 2010.

[5] Wang, Y. S., Wu, S. C., Lin, H. H. and Wang, Y. Y. , The relationship of service failure severity, service recovery justice and perceived switching costs with customer loyalty in the context of e-tailing, International Journal of Information Management, 31(4), pp. 350-359, 2011

[6] $\mathrm{Wu}, \mathrm{L}$. , Satisfaction, inertia, and customer loyalty in the varying levels of the zone of tolerance and alternative attractiveness, Journal of Services Marketing, 25(5), pp. 310 - 322, 2011.

[7] Yang, X. C. , Switching costs between customer satisfaction and loyalty empirical evidence from broadband services in mainland China, Computational Sciences and Optimization, 1, pp. 768-772, 2011. 